\title{
REVIEW
}

\section{Antibiotic stewardship in the intensive care unit}

\author{
Charles-Edouard Luyt*, Nicolas Bréchot, Jean-Louis Trouillet and Jean Chastre
}

\begin{abstract}
The rapid emergence and dissemination of antimicrobial-resistant microorganisms in ICUs worldwide constitute a problem of crisis dimensions. The root causes of this problem are multifactorial, but the core issues are clear. The emergence of antibiotic resistance is highly correlated with selective pressure resulting from inappropriate use of these drugs. Appropriate antibiotic stewardship in ICUs includes not only rapid identification and optimal treatment of bacterial infections in these critically ill patients, based on pharmacokinetic-pharmacodynamic characteristics, but also improving our ability to avoid administering unnecessary broad-spectrum antibiotics, shortening the duration of their administration, and reducing the numbers of patients receiving undue antibiotic therapy. Either we will be able to implement such a policy or we and our patients will face an uncontrollable surge of very difficult-to-treat pathogens.
\end{abstract}

\section{Introduction}

Optimal antibiotic use is crucial in the critical care setting, especially in an era of rising antibiotic resistance and lack of new antimicrobial development [1-3]. Study results indicate that $30 \%$ to $60 \%$ of antibiotics prescribed in ICUs are unnecessary, inappropriate, or suboptimal [4-7]. Overprescribing and misprescribing antibiotics are undoubtedly contributing to the growing challenges posed by antibioticresistant bacteria, and epidemiological studies have clearly demonstrated direct relationships between antibiotic consumption and the emergence and dissemination of resistant strains in hospitals and ICUs [7-20]. As defined by the Society of Healthcare Epidemiology of America and Infectious Diseases Society of America (IDSA) Joint Committee on the Prevention of Antimicrobial Resistance in hospitals, 'stewardship of antimicrobials is an apt descriptor of related activities that help optimize antimicrobial therapy, ensuring the best clinical outcome for the patient while lowering the risk of subsequent development of antimicrobial resistance' [14]. Thus, in-ICU antibiotic stewardship encompasses rapid identification of patients with bacterial infections, better empirical treatment selection, using pharmacokinetic-pharmacodynamic (PK-PD) characteristics to optimize antibiotic dosing and administration modalities, de-escalation once culture results become

\footnotetext{
* Correspondence: charles-edouard.luyt@psl.aphp.fr

Medical-Surgical Intensive Care Unit, ICAN, Institute of Cardiometabolism and Nutrition, Hôpital de la Pitié-Salpêtrière, Assistance Publique-Hôpitaux de Paris, Université Pierre et Marie Curie, Paris 6, 47, bd de l'Hôpital, 75651 Paris, Cedex 13, France
}

available, shortening therapy duration, and reducing the numbers of patients treated unnecessarily.

Unfortunately, improving in-ICU antibiotic use is particularly difficult for three main reasons: infection severity often precludes withdrawing or postponing antibiotics, the complex decision-making process frequently involves doctors with limited expertise, and it is difficult to ensure disease-long continuity of care by the same medical team 24 hours a day, 7 days a week. Here, we review how inICU antibiotic therapy could possibly be optimized and rationalized.

\section{Rapid identification of intensive care unit patients with bacterial infections}

Most published observational data suggest that the time to appropriate antibiotic administration is a major outcome determinant for ICU patients with severe bacterial infections. Indeed, each hour of delay in administering effective antibiotics for septic shock is associated with measurably increased mortality [6,21-25]. Thus, as strongly recommended by all guidelines [26-29], obtaining biological specimens should not postpone timely antibiotic administration to patients with severe sepsis or septic shock.

However, owing to methodological concerns, the harmful effects of inadequate therapy are not accepted by all [30-36]. Because in-ICU signs and symptoms of infection due to non-infectious causes are common, rushing to prescribe antibiotics may mean that many uninfected patients receive unnecessary treatment. In a quasi-experimental, before-and-after, observational cohort study of patients

\section{Biomed Central}

(c) 2014 Luyt et al.; licensee BioMed Central Ltd. The licensee has exclusive rights to distribute this article, in any medium, for 12 months following its publication. After this time, the article is available under the terms of the Creative Commons Attribution License (http://creativecommons.org/licenses/by/4.0), which permits unrestricted use, distribution, and reproduction in any medium, provided the original work is properly credited. The Creative Commons Public Domain Dedication waiver (http://creativecommons.org/publicdomain/zero/1.0) applies to the data made available in this article, unless otherwise stated. 
admitted to the University of Virginia surgical ICU, Hranjec and colleagues [32] postulated that delaying antibiotics for hemodynamically stable patients with suspected infections (35\% pneumonia) until they were objectively documented would not worsen mortality. Notably, that conservative approach was associated with lower all-cause mortality, more initially appropriate therapy, and shorter mean treatment duration than the aggressive strategy. Thus, for clinically stable patients, that strategy might achieve better antibiotic use without impacting prognosis. Obtaining specimens for appropriate cultures before antibiotic administration is essential to confirm infection, identify responsible pathogens, and enable therapy de-escalation in response to susceptibility profiles.

The inaccuracy of conventional approaches to diagnose hospital-acquired infections (HAIs) and the impossibility of those strategies to avoid antibiotic overprescription led some investigators to hypothesize that using biological markers for example, C-reactive protein, soluble-triggering receptor expressed on myeloid cells-1, or procalcitonin (PCT) might better identify true bacterial infections and facilitate therapeutic decisions. However, although PCT is a good marker of community-acquired infections (CAIs), it does not seem to be for HAIs [37-41]. Indeed, blood PCT concentrations can rise in various non-septic conditions: major trauma, surgery, acute respiratory distress syndrome, multiorgan failure, post-transplantation rejection, cardiogenic shock, severe burns, heat stroke, and so on. Thus, high PCT concentrations the day sepsis is suspected are non-contributory because increases that are attributable to a prior non-infectious condition or active infection cannot be distinguished $[39,42,43]$. Moreover, PCT can remain low in some microbiologically proven bacterial infections, either because the infection remains contained in a tissue compartment that can synthesize PCT locally without systemic release, thereby explaining the low serum level despite true infection, or because of a 24- to 48-hour lag time in infection onset to peak PCT release. Thus, intensivists are rightly reluctant to rely exclusively on biological markers when severe infection is suspected [37,38,43-47].

\section{Selection of initial antibiotic therapy}

Owing to the emergence of multiresistant Gram-negative bacilli (GNB) (for example, Pseudomonas aeruginosa, extended-spectrum $\beta$-lactamase-producing Enterobacteriaceae, and carbapenemase-producing Klebsiella pneumoniae) and the increasing role of Gram-positive bacteria (like methicillin-resistant Staphylococcus aureus, or MRSA), empirical broad-spectrum antibiotics are justified for most ICU patients with clinically suspected HAIs [25-27,48]. Regimen choice should be based on local antimicrobial susceptibility patterns and anticipated side effects while considering the antibiotics received within the preceding
2 weeks and striving whenever possible not to use the same classes [49-51]. Having current and frequently updated knowledge of local bacteriological epidemiology increases the likelihood of prescribing appropriate initial antibiotics. Whether surveillance cultures could further improve empirical treatment selection for ICU patients with suspected hospital-acquired pneumonia (HAP) is still debated but certainly should be weighed when difficultto-treat microorganisms abound, making initial choices particularly risky $[52,53]$. Observational study results confirmed that initial regimens combining a broad-spectrum $\beta$-lactam and an aminoglycoside increased the proportion of appropriately treated patients compared with monotherapy or a combination of $\beta$-lactam and fluoroquinolone $[54,55]$. Only patients with mildly or moderately severe, early-onset infections and no specific risk factors (for example, prolonged hospitalization, immunosuppression, or recent prolonged antibiotics or a combination of these) can receive a relatively narrow-spectrum drug, like a nonpseudomonal third-generation cephalosporin.

For ICU patients admitted with health care-associated or community-onset infections or CAIs, more restraints for antimicrobial therapy selection are certainly possible. For example, it is increasingly recognized that applying current criteria for health care-associated pneumonia hospitalization for at least 2 days during the preceding 90 days, residence in a nursing home or extended-care facility, home intravenous (antibiotics or chemotherapy) therapy, and chronic dialysis or home wound care (or both) during the preceding 30 days - as indications for broadspectrum antibiotics may lead to overtreatment of many patients with pneumonia [ $>56-62]$. To address this conceptual limitation, investigators developed multiple riskassessment models that refine those criteria [61,63,64]. Available data suggest that the incidence of pathogens resistant to the usual in-patient IDSA-American Thoracic Society guideline-recommended antibiotic regimen (that is, a non-pseudomonal cephalosporin and a macrolide) is usually not significantly increased unless two or more risk factors are present, with prior antibiotic use or hospitalization and poor functional status being more important predictors of resistant bacteria than nursing-home residence alone [61]. Using such an algorithm could lead to fewer pneumonia patients unnecessarily receiving broadspectrum antibiotics.

Within the past decade, the way clinical microbiology laboratories identify microorganisms was revolutionized, leaving behind slow traditional methods based on phenotype characteristics (for example, growth on defined media, colony morphology, Gram staining, and biochemical reactions) incurring significant diagnosis delay, in exchange for new diagnostic techniques (real-time multiplex polymerase chain reaction and matrix-assisted laser desorption/ionization time-of-flight mass spectrometry) $[65,66]$. 
The latter, making possible rapid pathogen identification and their antimicrobial resistance patterns (at least for certain organisms), could undoubtedly promote earlier therapy appropriateness and de-escalation [67]. Multiple instrument platforms, marketed by well-established manufacturers, are beginning to displace or complement (or both) automated conventional phenotyping tools, providing accurate microbial identification from blood cultures within 1 to 2 hours. Nevertheless, it is unlikely that any of those new diagnostic methods will completely replace phenotyping for antibiotic susceptibility testing in the near future.

Pending the complete development of those abovementioned techniques, Bouza and colleagues [68] described simple microbiology laboratory-accessible, rapid, antimicrobial susceptibility E-tests directly on samples (lower respiratory tract or other biological specimens) to improve early appropriate in-ICU antimicrobial choices. In a prospective randomized study of 250 patients with microbiologically confirmed ventilator-associated pneumonia (VAP), the authors showed that reporting rapid E-test-obtained antibiotic susceptibility of responsible microorganisms to the treating physicians (mean \pm standard deviation: $1.4 \pm 0.75$ days post-sampling versus 4.2 days with standard methods) was associated with fewer days of fever and antibiotics until VAP-episode resolution, less antibiotic consumption, less Clostridium difficile-associated diarrhea, lower antimicrobial costs, and fewer days on mechanical ventilation (MV) [68].

\section{Pharmacokinetic-pharmacodynamic-optimized antimicrobial therapy}

Reported findings demonstrated the need to individually adjust the antibiotic target doses and administration modalities to treat severe bacterial infection to each patient's
PK and putative or documented pathogens' susceptibilities, as assessed by their minimal inhibitory concentrations (MICs) [69-73]. Most investigators distinguish antimicrobials by their killing mechanism: concentration-dependent (for example, aminoglycosides and fluoroquinolones) or timedependent (for example, $\beta$-lactams and carbapenem). The most important PK-PD parameters are peak concentration/ MIC >8-10 and 24-hour area under the concentration curve (AUC)/MIC >100-125 for aminoglycosides and fluoroquinolones. For $\beta$-lactams and carbapenem, the blood concentration should be maintained for $>90-100 \%$ of the between-dose interval above MIC, at least in the case of severe infection $[74,75]$. However, it should be acknowledged that the exact target for PK-PD-optimized therapy remains elusive. Some antibiotics, such as fluoroquinolones and glycopeptides, are more complex and exhibit both concentration- and time-dependent kill characteristics where the best predictor of efficacy is the AUC/ MIC. Others, such as carbapenems, have a marked postantibiotic effect (that is, lead to a prolonged suppression of bacterial growth even with antibiotic concentrations below the MIC) [76,77].

ICU patients' altered PK secondary to increased volume of distribution and decreased elimination can result in insufficient serum aminoglycosides or $\beta$-lactam concentrations (or both) when standard doses are administered, emphasizing the need to carefully monitor peak and trough antibiotic levels when treating resistant pathogens, respectively $[5,78,79]$. Antibiotic doses for ICU patients derived from other patient groups are likely to be suboptimal because of significant antibiotic PK changes, particularly volume of distribution and clearance. Organ support techniques, including renal replacement therapy and extracorporeal membrane oxygenation, increase PK variability (Figure 1) [80-82]. In a recent prospective study

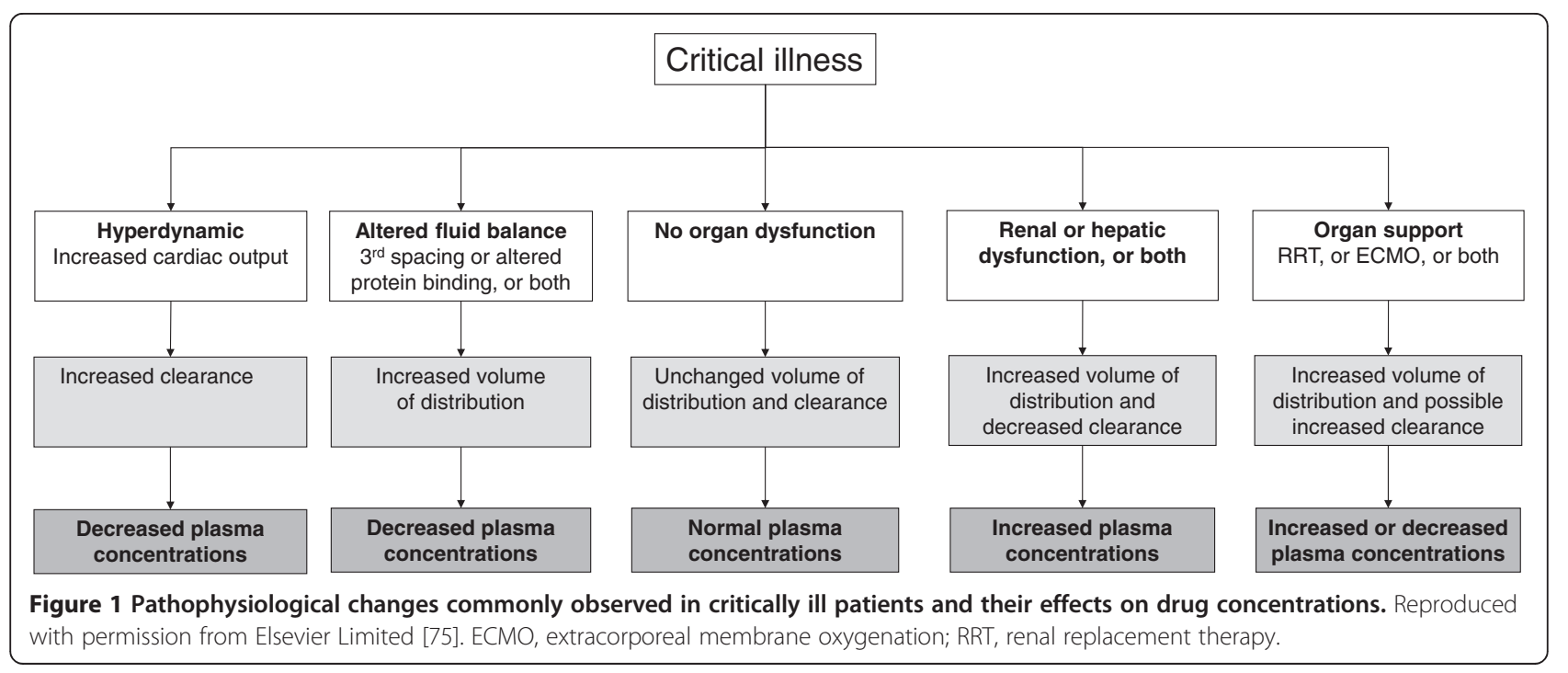


conducted at 64 hospitals worldwide, $20 \%$ and $40 \%$ of 248 ICU patients receiving $\beta$-lactams for infection did not achieve free antibiotic concentrations above their pathogens' MICs during 50\% and $100 \%$ (50\% and $100 \% f \mathrm{~T}>$ MIC, respectively) of the dosing interval (Figure 2) [5]. Frequently, higher than usually recommended antibiotic doses or continuous or extended infusions (or a combination of these) are needed [5,70,71,73,79,83-85]. Interestingly, use of prolonged infusion appeared to be associated with a significant reduction in mortality and improvement in clinical success when compared with intermittent boluses in a recent meta-analysis of 29 studies (18 randomized controlled trials and 11 observational studies) with a total of 2,206 patients [85].

Development of a priori dosing algorithms based on MIC, creatinine clearance and weight, and the clinicianspecified AUC target might improve management of these patients, obtaining more precise antibiotic use than current guidelines $[73,79,83,84,86]$. Ultimately, adjusting antibiotic doses based on pathogen MICs and daily free antibiotic blood concentrations may reach optimized PKPD targets in most ICU patients. A therapeutic drugmonitoring strategy, compared with traditional dosing methods, might not only reduce clinical failure rates in ICU patients but also prevent adverse events due to too high (toxic) antibiotic levels $[87,88]$.
A double-blind randomized trial comparing 7 days of doripenem three times a day (4-hour infusion of 1 gram) with 10 days of imipenem-cilastin (1-hour infusion of 1 gram) for GNB VAP was prematurely stopped after random assignment of 274 patients because of inferior efficacy and higher day- 28 all-cause mortality in the subgroup of doripenem-treated, $P$. aeruginosa-infected patients [89]. Despite longer doripenem infusions to optimize targeted antibiotic concentrations above the pathogens' MICs during the 8-hour interval, this protocol performed more poorly, clearly documenting the risk associated with a so-called PK-PD-optimized antibiotic strategy when blood concentrations cannot be monitored and adjusted to stay above the responsible pathogens' MICs. Perhaps the treatment duration or concentrations (or both) were sub-therapeutic for patients with elevated creatinine clearance, clearly documenting the risk associated with a so-called PK-PD-optimized antibiotic strategy when blood concentrations cannot be monitored and adjusted to stay above the MIC of the responsible pathogens [90].

For patients on MV, aerosolized antibiotics delivered via an efficient system, synchronized with inspiration, achieved airway drug concentrations 100- to 300-fold higher than the MICs of most bacteria, including multidrug-resistant pathogens [91-95]. Those levels, without systemic toxicity,

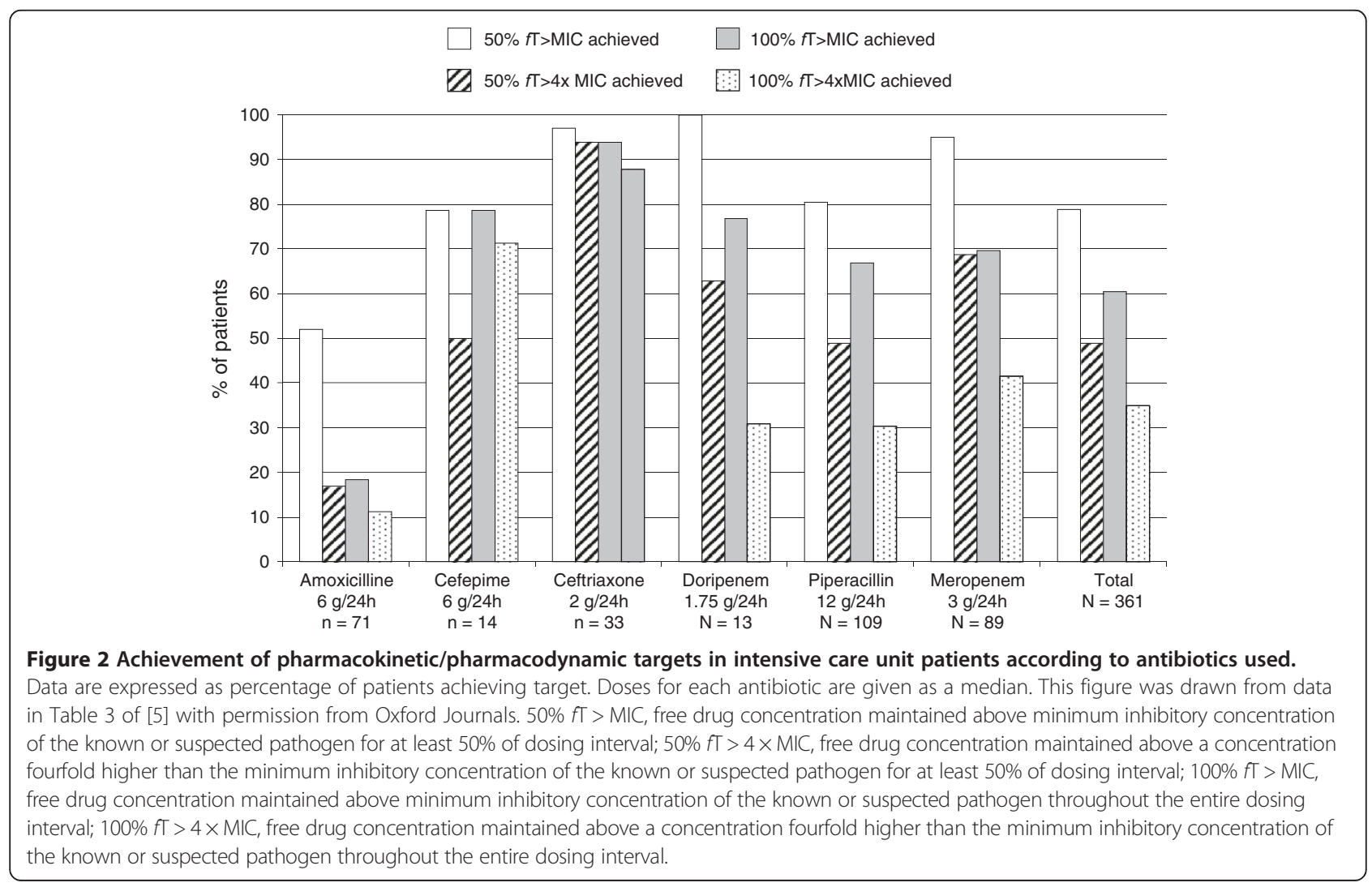


might eradicate proximal airway pathogens in patients on $\mathrm{MV}$ and lower the pressure for selection of new resistant organisms, as shown in a recent, double-blind, placebo-controlled study of 42 ICU patients who required prolonged MV and who were colonized or infected (or both) with potentially difficult-to-treat pathogens (for example, MRSA and non-fermenting GNB) [96]. However, larger clinical trials must confirm those findings before that strategy can be recommended, in light of its potentially deleterious impact on the local epidemiology when used for all ICU patients over prolonged periods [97-99].

\section{Antimicrobial therapy de-escalation}

The need to ensure that ICU patients with true bacterial infections receive prompt and appropriate antibiotics can lead to many more patients receiving antimicrobials than necessary, because of non-specific clinical signs of infection. This is particularly true for HAP/VAP, which represents the first in-ICU indication for starting antibiotics. Thus, regardless of the diagnostic strategy used for suspected HAP/VAP, serial clinical and microbiological evaluations are highly relevant to re-assess therapy after 48 to 72 hours and to stop it if infection is unlikely $[48,100]$. To accomplish that goal, each ICU should design its own diagnostic decision-tree strategy to manage patients with clinically suspected HAP/VAP to identify those with a low probability of infection, whose therapy can be discontinued when infection appears improbable $[27,48]$. At least, antibiotics should be withdrawn when the following three criteria are fulfilled on day 3: (a) the clinical diagnosis of pneumonia is unlikely - no definite infiltrates seen on repeat chest radiography and only one of the following three findings is present: temperature greater than $38.3^{\circ} \mathrm{C}$, leukocytosis (greater than $12,000 / \mathrm{mm}^{3}$ ) or leukopenia (less than $4,000 / \mathrm{mm}^{3}$ ), or purulent tracheobronchial secretions - or an alternative non-infectious diagnosis is confirmed; (b) non-significant tracheobronchial aspirate culture results; and (c) no severe sepsis or shock [101]. Direct examination of distal pulmonary samples collected by bronchoalveolar lavage with or without a bronchoscope and quantitative culture results have consistently yielded fewer microorganisms growing above the diagnostic threshold than qualitative tracheal aspirate cultures $[48,102]$. Pertinently, when therapeutic decisions were based on those results, compared with the clinical approach, fewer patients received antibiotics that were of a potentially narrower spectrum, thereby limiting the emergence and dissemination of drug-resistant strains and minimizing antibiotic-related toxicity [103].

For many ICU patients with infections (including lateonset infections), therapy can be de-escalated, once respiratory tract, blood, or other specimen culture results become available, if no resistant organism (for example, $P$. aeruginosa, Acinetobacter spp., or MRSA) is recovered or because the isolated pathogen is sensitive to a narrowerspectrum antibiotic than that prescribed empirically $[26,27,48]$. For example, if MRSA is not found, vancomycin and linezolid should be stopped unless the patient is allergic to $\beta$-lactams or has developed an infection with Gram-positive bacteria susceptible only to them. Verybroad-spectrum agents (like carbapenems, piperacillintazobactam, and cefepime) should also be restricted to patients whose infectious pathogens are susceptible only to them. Because fluoroquinolones have been associated with the emergence of resistant strains, their in-ICU use probably should be discouraged [104,105]. Antifungals should never be prescribed for Candida isolated from respiratory secretions alone [106]. However, clinicians should know that, when third-generation cephalosporins are chosen to treat infections caused by Enterobacteriacaea with inducible $\beta$-lacatamase (Enterobacter, Citrobacter, Morganella morganii, indole-positive Proteus, or Serratia spp.), the emergence of resistant variants may lead to treatment failure. Unfortunately, study results showed that deescalation, though not associated with any adverse outcomes, was not consistently applied in many ICUs [107-111].

The two most commonly cited reasons to prescribe combined antibiotics for the entire treatment duration are to achieve synergy and to prevent the emergence of resistant strains. However, antibiotic synergy has been shown to be valuable only in vitro and in patients with neutropenia, bacteremia, or a greater than $25 \%$ probability of death [25,112-122]. Randomized controlled trial results on combined therapy showed its benefit to be inconsistent or null, even when they were pooled in meta-analyses or when analysis was restricted to $P$. aeruginosa-infected patients $[113,121,123,124]$. Importantly, such regimens did not prevent the emergence of antimicrobial resistance during therapy and were associated with significantly more nephrotoxicity [121]. Those observations were confirmed in a randomized, open-label trial on 600 patients meeting criteria for severe sepsis or septic shock: combined meropenem and moxifloxacin versus meropenem alone did not achieve less organ failure or better survival or any secondary endpoints [113]. Based on those data, most patients' therapy could be safely switched to monotherapy after 3 to 5 days, provided that the initial therapy was appropriate, the clinical course evolved favorably, and microbiological data did not indicate difficult-to-treat microorganisms, with high in vitro MICs, as can be observed for some nonfermenting GNB.

\section{Shortening treatment duration}

Although shortening the duration of antibiotic administration for ICU patients may represent the most powerful strategy to reduce antibiotic impact on resistance emergence, most guidelines still recommend relatively prolonged or imprecise durations $[26,28,125,126]$. Efforts 
to shorten the duration for bacterial infections are justified by study results on the natural history of therapeutic responses. Most patients who had CAIs or HAIs, including VAP, and who received appropriate antimicrobial therapy had good clinical responses within the first 6 days [127-129]. Prolonged therapy facilitates colonization with antibiotic-resistant bacteria, which may precede recurrent infectious episodes.

Results of a multicenter, randomized controlled trial on 401 patients with microbiologically proven VAP showed that their clinical outcomes were similar to those of patients receiving appropriate empirical therapy for 8 or 15 days [130]. Relapse rates for short-duration therapy tended to be higher when $P$. aeruginosa or Acinetobacter spp. was the causative agent, but clinical outcomes were indistinguishable. Those observations were confirmed by trials that evaluated an antibiotic discontinuation policy for patients with other infections [111,131-138].

Many clinicians remain reluctant to prescribe fewer days of antibiotics for patients with severe HAIs and prefer tailoring antibiotic duration to the ensuing clinical course or using serial biomarker (for example, PCT) determinations (or both). The rationale for using the latter to customize treatment duration relies on evidence that the inflammatory response is often proportional to infection severity. When the response is absent or mild, antibiotics might logically be discontinued earlier. Thus, adapting treatment duration to PCT kinetics seems reasonable and was demonstrated to be useful in several randomized trials, including seven in the ICU, targeting patients with acute respiratory infections $[37,41,139-143]$. The largest of those studies was the PRORATA trial that included 621 ICU patients; $67 \%$ of these patients were on MV, $50 \%$ had CAIs, and $50 \%$ had HAIs, and half of them had septic shock [37]; patients in the PCT group had significantly more (mean \pm standard deviation) days without antibiotics than controls $(14.3 \pm 9.1$ versus $11.6 \pm 8.2$; absolute difference 2.7 days; 95\% confidence interval 1.4 to $4.1 ; P<0.0001$ ), and this lower antibiotic consumption was not associated with poorer outcomes. Furthermore, regardless of infection site and the infectious agent, results were consistent (Figure 3).

In summary, shortening the treatment duration for ICU patients with infections is possible and not detrimental for most of them. Indeed, the diversity of patients enrolled in those trials and the consistency of the findings suggest that the conclusions may be applicable to most critically ill patients who develop infections, including severe sepsis or septic shock, with the possible exception of those who are immunosuppressed, those who are infected with multiresistant microorganisms or whose course deteriorates despite treatment, or those whose initial regimen was inappropriate for the responsible pathogens. That strategy should help contain health-care costs and limit in-ICU emergence of bacterial resistance.

\section{Implementing a structured antibiotic stewardship program}

Optimizing in-ICU antimicrobial therapy is difficult. No single measure alone can succeed, emphasizing the need to devise a structured antibiotic stewardship program. Unfortunately, the exact set of key interventions essential to this multifaceted and multidisciplinary 'care bundle' remains unknown, as do the factors contributing to its success $[1,3,109,144-146]$. The interventions should be packaged so that compliance is readily assessable and achievable, which usually means that each bundle includes no more than five to eight interventions. Table 1 provides an example of antibiotic stewardship for patients with VAP. Successful implementation requires an interdisciplinary team, educational interventions, system innovations, process indicator evaluation, and feedback to health-care workers. Several studies using quasi-experimental designs confirmed the usefulness of such a strategy to optimize in-ICU antibiotic stewardship, but not all designs proved to be effective $[111,147,148]$. As the results of a recent study [149] showed, simply having a reference checklist, without a robust implementation-and-adherence strategy, is unlikely to improve patient outcomes $[149,150]$.

Computerized decision-support programs linked to electronic patient records can facilitate the dissemination of information to physicians for immediate use in therapeutic decision making and improving quality of care [151-154]. Partially or non-automated protocols, often instigated by hospital-based quality-improvement teams, also had demonstrated efficacy [154-157]. A prospective intervention of having an infectious disease specialist interact regularly with the medical ICU team was conducted to assess guideline compliance and antibiotic and health-care costs; it achieved significantly reduced use of extendedspectrum penicillins, carbapenems, vancomycin, and metronidazole [157]. Specifically, the intervention group had a significantly lower rate of treatments not corresponding to guidelines, with fewer MV days, shorter stays, and lower in-hospital mortality. Moreover, \$89,944 was saved for early antibiotic discontinuation alone [157].

\section{Conclusions}

The high antibiotic resistance observed in ICU patients who develop infections limits treatment options and justifies using regimens combining several broad-spectrum antibiotics, even when the presumed infection probability is low, because initial inappropriate therapy has been linked to poor prognoses. More than its economic impact, this 'spiraling empirical' practice increasingly leads to undue antibiotic administration to many ICU patients without true infections, paradoxically causing the emergence of more antibiotic-resistant microorganisms causing infections that, in turn, are associated with heightened mortality and morbidity. Therefore, antibiotic therapy for ICU 


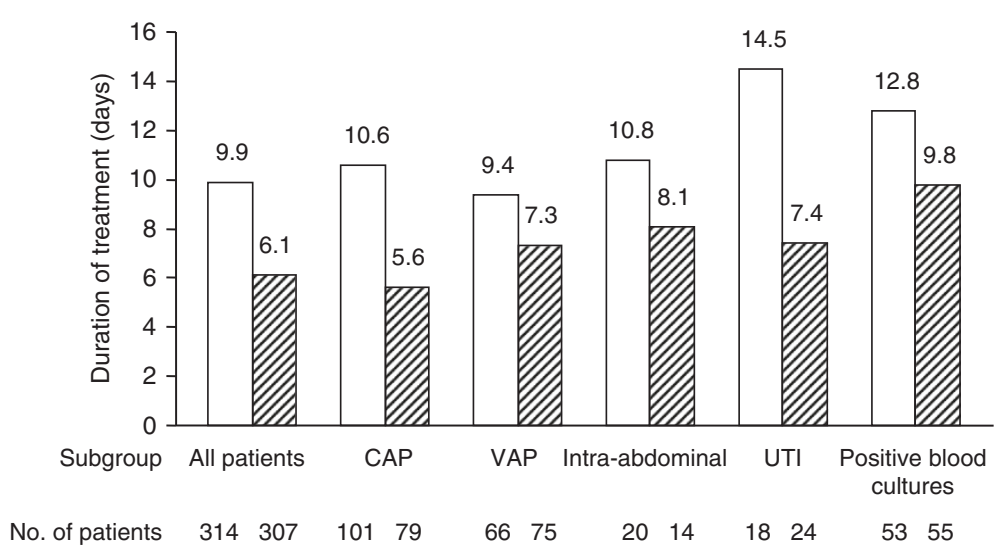

Figure 3 Duration of antibiotic treatment of the first episode in the PRORATA trial, according to infection site. White bars indicate patients included in the control group. Hatched bars indicate patients included in the procalcitonin-guided group. This figure was drawn from data in Table 2 of [37] with permission from Elsevier Limited. CAP, community-acquired pneumonia; PRORATA, Use of Procalcitonin to Reduce Patients' Exposure to Antibiotics in Intensive Care Units; UTI, urinary tract infection; VAP, ventilator-associated pneumonia.

patients with infections should be viewed as a two-stage process: the first involves administering broad-spectrum antibiotics to avoid inappropriate treatment of true bacterial infections, and the second focuses on trying to achieve the first without antibiotic overuse or abuse. In general, the first goal can be accomplished by rapidly identifying patients with infection and starting empirical therapy likely to treat the institution's most common etiological agents. This strategy requires that initial antibiotic choices be guided by local antibiotic resistance patterns and laboratory test results (including Gram staining), rapidly yielding identities of likely responsible pathogens. The second aim involves stopping therapy when the probability of infection is low, focusing and narrowing treatment once the microorganism is known, switching to monotherapy after day 3 whenever possible, and shortening treatment to 7 to 8 days for most patients, based on the clinical response and bacteriology findings. Therefore, every effort

Table 1 A personal care bundle for optimizing antimicrobial treatment for intensive care unit patients with ventilatorassociated pneumonia

\begin{tabular}{|c|c|}
\hline Antibiotic stewardship items & Rationale \\
\hline $\begin{array}{l}\text { Step 1: Obtain bronchoalveolar specimens } \\
\text { for Gram staining and cultures before } \\
\text { introducing new antibiotics. }\end{array}$ & $\begin{array}{l}\text { Every effort should be made to obtain reliable specimens from the specific infection site } \\
\text { for direct microscope examination and cultures in order to enable de-escalation. }\end{array}$ \\
\hline $\begin{array}{l}\text { Step 2: Start antibiotics less than } 2 \text { hours } \\
\text { after bronchoalveolar lavage. }\end{array}$ & $\begin{array}{l}\text { Time to appropriate antimicrobial administration is a major outcome determinant for intensive } \\
\text { care unit patients with severe bacterial infections. }\end{array}$ \\
\hline $\begin{array}{l}\text { Step 3: Start therapy using broad-spectrum } \\
\text { antibiotics unless no risk factors for resistant } \\
\text { pathogens are present. }\end{array}$ & $\begin{array}{l}\text { Owing to the emergence of multiresistant GNB (for example, Pseudomonas aeruginosa and } \\
\text { ESBL-producing GNB), empirical broad-spectrum antibiotics are justified for most patients with } \\
\text { clinically suspected VAP. }\end{array}$ \\
\hline $\begin{array}{l}\text { Step 4: Stop therapy on day } 3 \text { if infection } \\
\text { becomes unlikely. }\end{array}$ & $\begin{array}{l}\text { Antibiotics can be discontinued very early when VAP diagnosis becomes highly unlikely based } \\
\text { on negative cultures and clinical course and the elimination of an extrapulmonary infection. }\end{array}$ \\
\hline $\begin{array}{l}\text { Step 5: Use pharmacokinetic-pharmacodynamic } \\
\text { data to optimize treatment. }\end{array}$ & $\begin{array}{l}\text { Clinical and bacteriological outcomes can be improved by optimizing the therapeutic regimen } \\
\text { according to pharmacokinetic-pharmacodynamic properties of the selected agents. }\end{array}$ \\
\hline $\begin{array}{l}\text { Step 6: Streamline antibiotic therapy by } \\
\text { using narrower-spectrum antibiotics once } \\
\text { the etiological agent is identified. }\end{array}$ & $\begin{array}{l}\text { For many patients with VAP, including those with late-onset infections, therapy can be narrowed } \\
\text { once respiratory tract and blood culture results become available, either because an anticipated } \\
\text { bacterium (for example, P. aeruginosa, Acinetobacter spp., or methicillin-resistant Staphylococcus } \\
\text { aureus) was not recovered or because the isolated pathogen is sensitive to a narrower-spectrum } \\
\text { antibiotic than that used initially. }\end{array}$ \\
\hline Step 7: Switch to monotherapy on days 3 to 5. & $\begin{array}{l}\text { Using a two-antibiotic regimen for more than } 3 \text { to } 5 \text { days has no clinical benefits, provided that } \\
\text { initial therapy was appropriate, the clinical course evolves favorably, and microbiological data } \\
\text { exclude difficult-to-treat microorganisms. }\end{array}$ \\
\hline $\begin{array}{l}\text { Step 8: Shorten the treatment duration based } \\
\text { on procalcitonin kinetics. }\end{array}$ & $\begin{array}{l}\text { Shorter antibiotic administration for patients with VAP has achieved good outcomes with less } \\
\text { antibiotic consumption. Prolonged therapy leads to colonization with antibiotic-resistant bacteria, } \\
\text { which may precede recurrent VAP episodes. }\end{array}$ \\
\hline
\end{tabular}


should be made to obtain reliable specimens from the specific suspected infection site in each patient for direct microscope examination and cultures in order to deescalate antibiotics.

\section{Key messages}

- The rapid in-ICU emergence and dissemination of multidrug-resistant microorganisms worldwide constitute a problem of crisis dimensions that is linked directly to inappropriate antimicrobial use.

- Appropriate antibiotic stewardship is a two-stage process.

- Stage I includes rapidly identifying patients with infection, starting an empirical regimen likely to treat the institution's most common etiological agents, and optimizing bacterial killing by adjusting antibiotic doses and administration modalities based on PK-PD characteristics.

- Stage II involves stopping therapy in patients unlikely to have infections, focusing and narrowing treatment once the responsible pathogen is known, switching to monotherapy after day 3 whenever possible, and shortening antibiotic administration to 7 to 8 days for most patients, based on the therapeutic response and microbiology data.

- Any antibiotic stewardship program should be implemented in a structured manner and requires an interdisciplinary team, educational interventions, system innovations, process indicator evaluation, and feedback to health-care workers.

\section{Note}

This article is part of a series on Antibiotic resistance in the ICU, edited by Steven Opal. Other articles in this series can be found at http://ccforum.com/series/ antibioticresistance.

\section{Abbreviations \\ AUC: Area under the concentration curve; CAl: Community-acquired infection; GNB: Gram-negative bacilli; HAl: Hospital-acquired infection; HAP: Hospital-acquired pneumonia; IDSA: Infectious Diseases Society of America; MIC: Minimal inhibitory concentration; MRSA: Methicillin-resistant Staphylococcus aureus; MV: Mechanical ventilation; PCT: Procalcitonin; PK-PD: Pharmacokinetic-pharmacodynamic; VAP: Ventilator-associated pneumonia.}

\section{Competing interests}

C-EL has received lecture honoraria from or served on the advisory board of Thermo Fisher Brahms (Hennigsdorf, Germany), MSD (Whitehouse Station, NJ, USA), bioMérieux (Craponne, France), and Bayer (Leverkusen, Germany). JC has received lecture honoraria from or served on the advisory board of Astellas Pharma (Tokyo, Japan), Bayer/Nektar (San Francisco, CA, USA), Cubist (Lexington, MA, USA), Janssen-Cilag (Issy-les-Moulineaux, France), Pfizer (New York, NY, USA), and Sanofi Pasteur/KaloBios (Lyon, France). The other authors declare that they have no competing interests.

Published online: 13 August 2014

\section{References}

1. Arnold HM, Micek ST, Skrupky LP, Kollef MH: Antibiotic stewardship in the intensive care unit. Semin Respir Crit Care Med 2011, 32:215-227.

2. Laxminarayan R, Duse A, Wattal C, Zaidi AK, Wertheim HF, Sumpradit N, Vlieghe E, Hara GL, Gould IM, Goossens H, Greko C, So AD, Bigdeli M, Tomson G, Woodhouse W, Ombaka E, Peralta AQ, Qamar FN, Mir F, Kariuki S, Bhutta ZA, Coates A, Bergstrom R, Wright GD, Brown ED, Cars O: Antibiotic resistance - the need for global solutions. Lancet Infect Dis 2013, 13:1057-1098.

3. Leuthner KD, Doern GV: Antimicrobial stewardship programs. J Clin Microbiol 2013, 51:3916-3920.

4. Bergmans DC, Bonten MJ, Gaillard CA, van Tiel FH, van der Geest S, de Leeuw PW, Stobberingh EE: Indications for antibiotic use in ICU patients: a one-year prospective surveillance. J Antimicrob Chemother 1997, 39:527-535.

5. Roberts JA, Paul SK, Akova M, Bassetti M, De Waele JJ, Dimopoulos G, Kaukonen KM, Koulenti D, Martin C, Montravers P, Rello J, Rhodes A, Starr T, Wallis SC, Lipman J: DALI: defining antibiotic levels in intensive care unit patients: are current beta-lactam antibiotic doses sufficient for critically ill patients? Clin Infect Dis 2014, 58:1072-1083.

6. Kollef $\mathrm{MH}$ : Optimizing antibiotic therapy in the intensive care unit setting. Crit Care 2001, 5:189-195.

7. Kollef $\mathrm{MH}$, Fraser $\mathrm{VJ}$ : Antibiotic resistance in the intensive care unit. Ann Intern Med 2001, 134:298-314.

8. McGowan JE: Antimicrobial resistance in hospital organisms and its relation to antibiotic use. Rev Infect Dis 1983, 5:1033-1048.

9. Goldmann DA, Weinstein RA, Wenzel RP, Tablan OC, Duma RJ, Gaynes RP, Schlosser J, Martone WJ: Strategies to prevent and control the emergence and spread of antimicrobial-resistant microorganisms in hospitals, A challenge to hospital leadership. JAMA 1996, 275:234-240.

10. Lipsitch M, Bergstrom CT, Levin BR: The epidemiology of antibiotic resistance in hospitals: paradoxes and prescriptions. Proc Natl Acad Sci U S A 2000, 97:1938-1943.

11. MacDougall C, Polk RE: Antimicrobial stewardship programs in health care systems. Clin Microbiol Rev 2005, 18:638-656.

12. Paterson DL: The role of antimicrobial management programs in optimizing antibiotic prescribing within hospitals. Clin Infect Dis 2006, 42:S90-S95.

13. Rice LB: The maxwell finland lecture: for the duration-rational antibiotic administration in an era of antimicrobial resistance and clostridium difficile. Clin Infect Dis 2008, 46:491-496.

14. Shlaes DM, Gerding DN, John JF Jr, Craig WA, Bornstein DL, Duncan RA, Eckman MR, Farrer WE, Greene WH, Lorian V, Levy S, McGowan JE Jr, Paul SM, Ruskin J, Tenover FC, Watanakunakorn C: Society for Healthcare Epidemiology of America and Infectious Diseases Society of America joint committee on the prevention of antimicrobial resistance: guidelines for the prevention of antimicrobial resistance in hospitals. Clin Infect Dis 1997, 25:584-599.

15. Sievert DM, Ricks P, Edwards JR, Schneider A, Patel J, Srinivasan A, Kallen A, Limbago B, Fridkin S: Antimicrobial-resistant pathogens associated with healthcare-associated infections: summary of data reported to the national healthcare safety network at the centers for disease control and prevention, 2009-2010. Infect Control Hosp Epidemiol 2013, 34:1-14.

16. Thomas JK, Forrest A, Bhavnani SM, Hyatt JM, Cheng A, Ballow CH, Schentag JJ: Pharmacodynamic evaluation of factors associated with the development of bacterial resistance in acutely ill patients during therapy. Antimicrob Agents Chemother 1998, 42:521-527.

17. Zillich AJ, Sutherland JM, Wilson SJ, Diekema DJ, Ernst EJ, Vaughn TE, Doebbeling BN: Antimicrobial use control measures to prevent and control antimicrobial resistance in US hospitals. Infect Control Hosp Epidemiol 2006, 27:1088-1095.

18. Armand-Lefevre L, Angebault C, Barbier F, Hamelet E, Defrance G, Ruppe E, Bronchard R, Lepeule R, Lucet JC, El Mniai A, Wolff M, Montravers P, Plesiat $P$, Andremont $A$ : Emergence of imipenem-resistant gram-negative bacill in intestinal flora of intensive care patients. Antimicrob Agents Chemother 2013, 57:1488-1495.

19. Malhotra-Kumar S, Lammens C, Coenen S, Van Herck K, Goossens H: Effect of azithromycin and clarithromycin therapy on pharyngeal carriage of macrolide-resistant streptococci in healthy volunteers: a randomised, double-blind, placebo-controlled study. Lancet 2007, 369:482-490.

20. Landman D, Quale JM, Mayorga D, Adedeji A, Vangala K, Ravishankar J, Flores C, Brooks S: Citywide clonal outbreak of multiresistant 
Acinetobacter baumannii and Pseudomonas aeruginosa in Brooklyn, NY: the preantibiotic era has returned. Arch Intern Med 2002, 162:1515-1520.

21. Kollef $\mathrm{MH}$ : Inadequate antimicrobial treatment: an important determinant of outcome for hospitalized patients. Clin Infect Dis 2000, 31:S131-S138

22. Kollef MH, Sherman G, Ward S, Fraser VJ: Inadequate antimicrobial treatment of infections: a risk factor for hospital mortality among critically ill patients. Chest 1999, 115:462-474.

23. Kumar A: Early antimicrobial therapy in severe sepsis and septic shock. Curr Infect Dis Rep 2010, 12:336-344.

24. Kumar A, Roberts D, Wood KE, Light B, Parrillo JE, Sharma S, Suppes R, Feinstein D, Zanotti S, Taiberg L, Gurka D, Cheang M: Duration of hypotension before initiation of effective antimicrobial therapy is the critical determinant of survival in human septic shock. Crit Care Med 2006, 34:1589-1596.

25. Kumar A, Zarychanski R, Light B, Parrillo J, Maki D, Simon D, Laporta D, Lapinsky S, Ellis P, Mirzanejad Y, Martinka G, Keenan S, Wood G, Arabi Y, Feinstein D, Dodek P, Kravetsky L, Doucette S: Early combination antibiotic therapy yields improved survival compared with monotherapy in septic shock: a propensity-matched analysis. Crit Care Med 2010, 38:1773-1785.

26. Dellinger RP, Levy MM, Rhodes A, Annane D, Gerlach H, Opal SM, Sevransky JE, Sprung CL, Douglas IS, Jaeschke R, Osborn TM, Nunnally ME, Townsend SR, Reinhart K, Kleinpell RM, Angus DC, Deutschman CS, Machado FR, Rubenfeld GD, Webb SA, Beale RJ, Vincent JL, Moreno R: Surviving sepsis campaign: international guidelines for management of severe sepsis and septic shock: 2012. Crit Care Med 2013, 41:580-637.

27. Guidelines for the management of adults with hospital-acquired, ventilator-associated, and healthcare-associated pneumonia. Am J Respir Crit Care Med 2005, 171:388-416.

28. Masterton RG, Galloway A, French G, Street M, Armstrong J, Brown E, Cleverley J, Dilworth P, Fry C, Gascoigne AD, Knox A, Nathwani D, Spencer R, Wilcox M: Guidelines for the management of hospital-acquired pneumonia in the UK: report of the working party on hospital-acquired pneumonia of the British Society for Antimicrobial Chemotherapy. $J$ Antimicrob Chemother 2008, 62:5-34.

29. Muscedere J, Dodek P, Keenan S, Fowler R, Cook D, Heyland D: Comprehensive evidence-based clinical practice guidelines for ventilator-associated pneumonia: diagnosis and treatment. J Crit Care 2008, 23:138-147.

30. Amaral AC, Holder MW: Timing of antimicrobial therapy after identification of ventilator-associated condition is not associated with mortality in patients with ventilator-associated pneumonia: a cohort study. PloS One 2014, 9:e97575.

31. Bloos F, Thomas-Ruddel D, Ruddel H, Engel C, Schwarzkopf D, Marshall JC, Harbarth S, Simon P, Riessen R, Keh D, Dey K, Weiss M, Toussaint S, Schadler D, Weyland A, Ragaller M, Schwarzkopf K, Eiche J, Kuhnle G, Hoyer H, Hartog C, Kaisers U, Reinhart K: Impact of compliance with infection management guidelines on outcome in patients with severe sepsis: a prospective observational multi-center study. Crit Care 2014, 18:R42.

32. Hranjec T, Rosenberger LH, Swenson B, Metzger R, Flohr TR, Politano AD, Riccio LM, Popovsky KA, Sawyer RG: Aggressive versus conservative initiation of antimicrobial treatment in critically ill surgical patients with suspected intensive-care-unit-acquired infection: a quasi-experimental, before and after observational cohort study. Lancet Infect Dis 2012, 12:774-780

33. Pines JM, Isserman JA, Hinfey PB: The measurement of time to first antibiotic dose for pneumonia in the emergency department: a white paper and position statement prepared for the American Academy of Emergency Medicine. J Emerg Med 2009, 37:335-340.

34. Quattromani E, Powell ES, Khare RK, Cheema N, Sauser K, Periyanayagam U, Pirotte MJ, Feinglass J, Mark Courtney D: Hospital-reported data on the pneumonia quality measure 'Time to first antibiotic dose' are not associated with inpatient mortality: results of a nationwide cross-sectional analysis. Acad Emerg Med 2011, 18:496-503.

35. Welker JA, Huston M, McCue JD: Antibiotic timing and errors in diagnosing pneumonia. Arch Intern Med 2008, 168:351-356.

36. Yahav D, Leibovici L, Goldberg E, Bishara J, Paul M: Time to first antibiotic dose for patients hospitalised with community-acquired pneumonia. Int J Antimicrob Agents 2013, 41:410-413.

37. Bouadma L, Luyt CE, Tubach F, Cracco C, Alvarez A, Schwebel C, Schortgen F, Lasocki S, Veber B, Dehoux M, Bernard M, Pasquet B, Regnier B, Brun-Buisson C,
Chastre J, Wolff M: Use of procalcitonin to reduce patients' exposure to antibiotics in intensive care units (prorata trial): a multicentre randomised controlled trial. Lancet 2010, 375:463-474.

38. Layios N, Lambermont B, Canivet JL, Morimont P, Preiser JC, Garweg C, Ledoux D, Frippiat F, Piret S, Giot JB, Wiesen P, Meuris C, Massion P, Leonard $P$, Nys $M$, Lancellotti $P$, Chapelle JP, Damas P: Procalcitonin usefulness for the initiation of antibiotic treatment in intensive care unit patients. Crit Care Med 2012, 40:2304-2309.

39. Luyt CE, Combes A, Trouillet JL, Chastre J: Value of the serum procalcitonin level to guide antimicrobial therapy for patients with ventilator-associated pneumonia. Semin Respir Crit Care Med 2011, 32:181-187.

40. Schuetz P, Albrich W, Christ-Crain M, Chastre J, Mueller B: Procalcitonin for guidance of antibiotic therapy. Expert Rev Anti Infect Ther 2010, 8:575-587.

41. Schuetz P, Muller B, Christ-Crain M, Stolz D, Tamm M, Bouadma L, Luyt CE, Wolff M, Chastre J, Tubach F, Kristoffersen KB, Burkhardt O, Welte T, Schroeder S, Nobre V, Wei L, Bhatnagar N, Bucher HC, Briel M: Procalcitonin to initiate or discontinue antibiotics in acute respiratory tract infections. Cochrane Database Syst Rev 2012, 9, CD007498.

42. Uzzan B, Cohen R, Nicolas P, Cucherat M, Perret GY: Procalcitonin as a diagnostic test for sepsis in critically ill adults and after surgery or trauma: a systematic review and meta-analysis. Crit Care Med 2006, 34:1996-2003.

43. Wacker C, Prkno A, Brunkhorst FM, Schlattmann P: Procalcitonin as a diagnostic marker for sepsis: a systematic review and meta-analysis. Lancet Infect Dis 2013, 13:426-435.

44. Quenot JP, Luyt CE, Roche N, Chalumeau M, Charles PE, Claessens YE, Lasocki S, Bedos JP, Pean Y, Philippart F, Ruiz S, Gras-Leguen C, Dupuy AM, Pugin J, Stahl JP, Misset B, Gauzit R, Brun-Buisson C: Role of biomarkers in the management of antibiotic therapy: An expert panel review ii: clinical use of biomarkers for initiation or discontinuation of antibiotic therapy. Ann Intensive Care 2013, 3:21.

45. Jensen JU, Hein L, Lundgren B, Bestle MH, Mohr TT, Andersen MH, Thornberg KJ, Loken J, Steensen M, Fox Z, Tousi H, Soe-Jensen P, Lauritsen AO, Strange D, Petersen PL, Reiter N, Hestad S, Thormar K, Fjeldborg P, Larsen KM, Drenck NE, Ostergaard C, Kjaer J, Grarup J, Lundgren JD: Procalcitonin-guided interventions against infections to increase early appropriate antibiotics and improve survival in the intensive care unit: a randomized trial. Crit Care Med 2011, 39:2048-2058.

46. Pfister R, Kochanek M, Leygeber T, Brun-Buisson C, Cuquemelle E, Paiva Machado MB, Piacentini E, Hammond NE, Ingram PR, Michels G: Procalcitonin for diagnosis of bacterial pneumonia in critically ill patients during 2009 H1N1 influenza pandemic: a prospective cohort study, systematic review and individual patient data meta-analysis. Crit Care 2014, 18:R44.

47. Annane D, Maxime V, Faller JP, Mezher C, Clec'h C, Martel P, Gonzales H, Feissel M, Cohen Y, Capellier G, Gharbi M, Nardi O: Procalcitonin levels to guide antibiotic therapy in adults with non-microbiologically proven apparent severe sepsis: a randomised controlled trial. BMJ Open 2013, 3:pii: e002186.

48. Chastre J, Fagon JY: Ventilator-associated pneumonia. Am J Respir Crit Care Med 2002, 165:867-903.

49. Trouillet JL, Vuagnat A, Combes A, Kassis N, Chastre J, Gibert C: Pseudomonas aeruginosa ventilator-associated pneumonia: comparison of episodes due to piperacillin-resistant versus piperacillin-susceptible organisms. Clin Infect Dis 2002, 34:1047-1054.

50. Carmeli Y, Troillet N, Eliopoulos GM, Samore MH: Emergence of antibioticresistant pseudomonas aeruginosa: comparison of risks associated with different antipseudomonal agents. Antimicrob Agents Chemother 1999, 43:1379-1382

51. Luyt CE, Aubry A, Lu Q, Micaelo M, Brechot N, Brossier F, Brisson H, Rouby JJ, Trouillet JL, Combes A, Jarlier V, Chastre J: Imipenem, meropenem, or doripenem to treat patients with pseudomonas aeruginosa ventilatorassociated pneumonia. Antimicrob Agents Chemother 2014, 58:1372-1380.

52. Brusselaers N, Labeau S, Vogelaers D, Blot S: Value of lower respiratory tract surveillance cultures to predict bacterial pathogens in ventilatorassociated pneumonia: systematic review and diagnostic test accuracy meta-analysis. Intensive Care Med 2013, 39:365-375.

53. Michel F, Franceschini B, Berger P, Arnal JM, Gainnier M, Sainty JM, Papazian L: Early antibiotic treatment for BAL-confirmed ventilator-associated pneumonia: a role for routine endotracheal aspirate cultures. Chest 2005, 127:589-597. 
54. Martinez JA, Cobos-Trigueros N, Soriano A, Almela M, Ortega M, Marco F, Pitart C, Sterzik H, Lopez J, Mensa J: Influence of empiric therapy with a beta-lactam alone or combined with an aminoglycoside on prognosis of bacteremia due to gram-negative microorganisms. Antimicrob Agents Chemother 2010, 54:3590-3596.

55. Micek ST, Welch EC, Khan J, Pervez M, Doherty JA, Reichley RM, Kollef MH: Empiric combination antibiotic therapy is associated with improved outcome against sepsis due to gram-negative bacteria: a retrospective analysis. Antimicrob Agents Chemother 2010, 54:1742-1748.

56. Chalmers JD, Taylor JK, Singanayagam A, Fleming GB, Akram AR, Mandal $P$, Choudhury G, Hill AT: Epidemiology, antibiotic therapy, and clinical outcomes in health care-associated pneumonia: a UK cohort study. Clin Infect Dis 2011, 53:107-113.

57. Garcia-Vidal C, Viasus D, Roset A, Adamuz J, Verdaguer R, Dorca J, Gudiol F, Carratala J: Low incidence of multidrug-resistant organisms in patients with healthcare-associated pneumonia requiring hospitalization. Clin Microbiol Infect 2011, 17:1659-1665.

58. Aliberti S, Di Pasquale M, Zanaboni AM, Cosentini R, Brambilla AM, Seghezzi S, Tarsia P, Mantero M, Blasi F: Stratifying risk factors for multidrug-resistant pathogens in hospitalized patients coming from the community with pneumonia. Clin Infect Dis 2012, 54:470-478.

59. Cardoso T, Ribeiro O, Aragao IC, Costa-Pereira A, Sarmento AE: Additional risk factors for infection by multidrug-resistant pathogens in healthcare-associated infection: a large cohort study. BMC Infect Dis 2012, 12:375.

60. Jeong BH, Koh WJ, Yoo H, Um SW, Suh GY, Chung MP, Kim H, Kwon OJ, Jeon K: Performances of prognostic scoring systems in patients with healthcare-associated pneumonia. Clin Infect Dis 2013, 56:625-632.

61. Shindo $Y$, Ito $R$, Kobayashi $D$, Ando M, Ichikawa M, Shiraki A, Goto $Y$, Fukui $Y$, Iwaki M, Okumura J, Yamaguchi I, Yagi T, Tanikawa Y, Sugino Y, Shindoh J, Ogasawara T, Nomura F, Saka H, Yamamoto M, Taniguchi H, Suzuki R, Saito $H$, Kawamura T, Hasegawa Y: Risk factors for drug-resistant pathogens in community-acquired and healthcare-associated pneumonia. Am J Respir Crit Care Med 2013, 188:985-995.

62. Chalmers JD, Rother C, Salih W, Ewig S: Healthcare-associated pneumonia does not accurately identify potentially resistant pathogens: a systematic review and meta-analysis. Clin Infect Dis 2014, 58:330-339.

63. Park SC, Kim EY, Kang YA, Park MS, Kim YS, Kim SK, Chang J, Jung JY: Validation of a scoring tool to predict drug-resistant pathogens in hospitalised pneumonia patients. Int J Tuberc Lung Dis 2013, 17:704-709.

64. Shorr AF, Zilberberg MD, Reichley R, Kan J, Hoban A, Hoffman J, Micek ST, Kollef $\mathrm{MH}$ : Validation of a clinical score for assessing the risk of resistant pathogens in patients with pneumonia presenting to the emergency department. Clin Infect Dis 2012, 54:193-198.

65. Clark AE, Kaleta EJ, Arora A, Wolk DM: Matrix-assisted laser desorption ionization-time of flight mass spectrometry: a fundamental shift in the routine practice of clinical microbiology. Clin Microbiol Rev 2013, 26:547-603.

66. Hrabak J, Chudackova E, Walkova R: Matrix-assisted laser desorption ionization-time of flight (MALDI-TOF) mass spectrometry for detection of antibiotic resistance mechanisms: from research to routine diagnosis. Clin Microbiol Rev 2013, 26:103-114.

67. Clerc O, Prod'hom G, Vogne C, Bizzini A, Calandra T, Greub G: Impact of matrix-assisted laser desorption ionization time-of-flight mass spectrometry on the clinical management of patients with gram-negative bacteremia: a prospective observational study. Clin Infect Dis 2013, 56:1101-1107.

68. Bouza E, Torres MV, Radice C, Cercenado E, de Diego R, Sanchez-Carrillo C, Munoz P: Direct E-test (AB Biodisk) of respiratory samples improves antimicrobial use in ventilator-associated pneumonia. Clin Infect Dis 2007, 44:382-387.

69. Arnold HM, Hollands JM, Skrupky LP, Smith JR, Juang PH, Hampton NB, McCormick S, Reichley RM, Hoban A, Hoffmann J, Micek ST, Kollef MH: Prolonged infusion antibiotics for suspected gram-negative infections in the ICU: a before-after study. Ann Pharmacother 2013, 47:170-180.

70. Dulhunty JM, Roberts JA, Davis JS, Webb SA, Bellomo R, Gomersall C, Shirwadkar C, Eastwood GM, Myburgh J, Paterson DL, Lipman J: Continuous infusion of beta-lactam antibiotics in severe sepsis: a multicenter double-blind, randomized controlled trial. Clin Infect Dis 2013, 56:236-244.

71. Shiu J, Wang E, Tejani AM, Wasdell M: Continuous versus intermittent infusions of antibiotics for the treatment of severe acute infections. Cochrane Database Syst Rev 2013, 3: CD008481.
72. Walker MC, Lam WM, Manasco KB: Continuous and extended infusions of beta-lactam antibiotics in the pediatric population. Ann Pharmacother 2012, 46:1537-1546.

73. Falagas ME, Tansarli GS, Ikawa K, Vardakas KZ: Clinical outcomes with extended or continuous versus short-term intravenous infusion of carbapenems and piperacillin/tazobactam: a systematic review and meta-analysis. Clin Infect Dis 2013, 56:272-282

74. Abdul-Aziz MH, Dulhunty JM, Bellomo R, Lipman J, Roberts JA: Continuous beta-lactam infusion in critically ill patients: the clinical evidence. Ann Intensive Care 2012, 2:37.

75. Roberts JA, Abdul-Aziz MH, Lipman J, Mouton JW, Vinks AA, Felton TW, Hope WW, Farkas A, Neely MN, Schentag JJ, Drusano G, Frey OR, Theuretzbacher $U$, Kuti $J$ : Individualised antibiotic dosing for patients who are critically ill: challenges and potential solutions. Lancet Infect Dis 2014, 14:498-509.

76. Baquero F, Culebras E, Patron C, Perez-Diaz JC, Medrano JC, Vicente MF: Postantibiotic effect of imipenem on gram-positive and gram-negative micro-organisms. J Antimicrob Chemother 1986, 18:47-59.

77. Spivey JM: The postantibiotic effect. Clin Pharm 1992, 11:865-875

78. Taccone FS, Laterre PF, Dugernier T, Spapen H, Delattre I, Wittebole X, De Backer D, Layeux B, Wallemaca P, Vincent JL, Jacobs F: Insufficient beta-lactam concentrations in the early phase of severe sepsis and septic shock. Crit Care 2010, 14:R126.

79. Duszynska W, Taccone FS, Hurkacz M, Kowalska-Krochmal B, Wiela-Hojenska A, Kubler A: Therapeutic drug monitoring of amikacin in septic patients. Crit Care 2013, 17:R165

80. Pea F, Viale P, Pavan F, Furlanut M: Pharmacokinetic considerations for antimicrobial therapy in patients receiving renal replacement therapy. Clin Pharmacokinet 2007, 46:997-1038.

81. Roberts DM, Roberts JA, Roberts MS, Liu X, Nair P, Cole L, Lipman J, Bellomo $\mathrm{R}$ : Variability of antibiotic concentrations in critically ill patients receiving continuous renal replacement therapy: a multicentre pharmacokinetic study. Crit Care Med 2012, 40:1523-1528.

82. Trotman RL, Williamson JC, Shoemaker DM, Salzer WL: Antibiotic dosing in critically ill adult patients receiving continuous renal replacement therapy. Clin Infect Dis 2005, 41:1159-1166.

83. Lodise TP, Drusano GL: Pharmacokinetics and pharmacodynamics: optimal antimicrobial therapy in the intensive care unit. Crit Care Clin 2011, 27:1-18.

84. Taccone FS, Laterre PF, Spapen H, Dugernier T, Delattre I, Layeux B, De Backer D, Wittebole X, Wallemacq P, Vincent JL, Jacobs F: Revisiting the loading dose of amikacin for patients with severe sepsis and septic shock. Crit Care 2010, 14:R53.

85. Teo J, Liew Y, Lee W, Kwa AL: Prolonged infusion versus intermittent boluses of beta-lactam antibiotics for treatment of acute infections: a meta-analysis. Int J Antimicrob Agents 2014, 43:403-411.

86. Delattre IK, Musuamba FT, Jacqmin P, Taccone FS, Laterre PF, Verbeeck RK, Jacobs F, Wallemacq P: Population pharmacokinetics of four beta-lactams in critically ill septic patients comedicated with amikacin. Clin Biochem 2012, 45:780-786.

87. Grill MF, Maganti RK: Neurotoxic effects associated with antibiotic use: management considerations. Br J Clin Pharmacol 2011, 72:381-393.

88. Naeije G, Lorent S, Vincent JL, Legros B: Continuous epileptiform discharges in patients treated with cefepime or meropenem. Arch Neurol 2011, 68:1303-1307.

89. Kollef MH, Chastre J, Clavel M, Restrepo MI, Michiels B, Kaniga K, Cirillo I, Kimko H, Redman R: A randomized trial of 7-day doripenem versus 10-day imipenem-cilastatin for ventilator-associated pneumonia. Crit Care 2012, 16:R218.

90. Udy AA, Baptista JP, Lim NL, Joynt GM, Jarrett P, Wockner L, Boots RJ, Lipman J: Augmented renal clearance in the ICU: results of a multicenter observational study of renal function in critically ill patients with normal plasma creatinine concentrations. Crit Care Med 2014, 42:520-527.

91. Luyt CE, Jacob A, Combes A, Nieszkowszka A, Fernandez C, Trouillet JL, Corkery K, Farinotti R, Chastre J: Nktr-061 (inhaled amikacin) achieves high epithelial lining fluid concentrations in gram-negative pneumonia in intubated and mechanically ventilated patients [abstract]. Am J Respir Crit Care Med 2007, 175:A328.

92. Niederman MS, Chastre J, Corkery K, Fink JB, Luyt CE, Garcia MS: Bay41-6551 achieves bactericidal tracheal aspirate amikacin concentrations in 
mechanically ventilated patients with gram-negative pneumonia. Intensive Care Med 2012, 38:263-271.

93. Palmer LB, Smaldone GC, Chen JJ, Baram D, Duan T, Monteforte M, Varela M, Tempone AK, O'Riordan T, Daroowalla F, Richman P: Aerosolized antibiotics and ventilator-associated tracheobronchitis in the intensive care unit. Crit Care Med 2008, 36:2008-2013.

94. Luyt CE, Combes A, Nieszkowska A, Trouillet JL, Chastre J: Aerosolized antibiotics to treat ventilator-associated pneumonia. Curr Opin Infect Dis 2009, 22:154-158.

95. Luyt CE, Eldon MA, Stass H, Gribben D, Corkery K, Chastre J: Pharmacokinetics and tolerability of amikacin administered as bay41-6551 aerosol in mechanically ventilated patients with gram-negative pneumonia and acute renal failure. J Aerosol Med Pulm Drug Deliv 2011, 24:183-190.

96. Palmer LB, Smaldone GC: Reduction of bacterial resistance with inhaled antibiotics in the ICU. Am J Respir Crit Care Med 2014, 189:1225-1233.

97. Stevens RM, Teres D, Skillman JJ, Feingold DS: Pneumonia in an intensive care unit. A 30-month experience. Arch Intern Med 1974, 134:106-111.

98. Buelow E, Gonzalez TB, Versluis D, Oostdijk EA, Ogilvie LA, van Mourik MS, Oosterink E, van Passel MW, Smidt H, D'Andrea MM, de Been M, Jones BV, Willems RJ, Bonten MJ, van Schaik W: Effects of selective digestive decontamination (SDD) on the gut resistome. J Antimicrob Chemother 2014, [Epub ahead of print].

99. Oostdijk EA, Smits L, de Smet AM, Leverstein-van Hall MA, Kesecioglu J, Bonten MJ: Colistin resistance in gram-negative bacteria during prophylactic topical colistin use in intensive care units. Intensive Care Med 2013, 39:653-660.

100. Singh N, Rogers $P$, Atwood CW, Wagener MM, Yu VL: Short-course empiric antibiotic therapy for patients with pulmonary infiltrates in the intensive care unit. A proposed solution for indiscriminate antibiotic prescription. Am J Respir Crit Care Med 2000, 162:505-511.

101. Torres A, Ewig S: Diagnosing ventilator-associated pneumonia. N Engl J Med 2004, 350:433-435.

102. Baselski VS, Wunderink RG: Bronchoscopic diagnosis of pneumonia. Clin Microbiol Rev 1994, 7:533-558.

103. Fagon JY, Chastre J, Wolff M, Gervais C, Parer-Aubas S, Stephan F, Similowski T, Mercat A, Diehl JL, Sollet JP, Tenaillon A: Invasive and noninvasive strategies for management of suspected ventilator-associated pneumonia. A randomized trial. Ann Intern Med 2000, 132:621-630.

104. Charbonneau P, Parienti JJ, Thibon P, Ramakers M, Daubin C, du Cheyron D, Lebouvier G, Le Coutour X, Leclercq R: Fluoroquinolone use and methicillin-resistant staphylococcus aureus isolation rates in hospitalized patients: a quasi experimental study. Clin Infect Dis 2006, 42:778-784.

105. Nseir S, Di Pompeo C, Soubrier S, Delour P, Lenci H, Roussel-Delvallez M, Onimus T, Saulnier F, Mathieu D, Durocher A: First-generation fluoroquinolone use and subsequent emergence of multiple drug-resistant bacteria in the intensive care unit. Crit Care Med 2005, 33:283-289.

106. Cornely OA, Bassetti M, Calandra T, Garbino J, Kullberg BJ, Lortholary O, Meersseman W, Akova M, Arendrup MC, Arikan-Akdagli S, Bille J, Castagnola E, Cuenca-Estrella M, Donnelly JP, Groll AH, Herbrecht R, Hope WW, Jensen HE, Lass-Florl C, Petrikkos G, Richardson MD, Roilides E, Verweij PE, Viscoli C, Ullmann AJ: Escmid* guideline for the diagnosis and management of candida diseases 2012: non-neutropenic adult patients. Clin Microbiol Infect 2012, 18:19-37.

107. Rello J, Vidaur L, Sandiumenge A, Rodriguez A, Gualis B, Boque C, Diaz E: De-escalation therapy in ventilator-associated pneumonia. Crit Care Med 2004, 32:2183-2190.

108. Giantsou E, Liratzopoulos N, Efraimidou E, Panopoulou M, Alepopoulou E, Kartali-Ktenidou S, Manolas K: De-escalation therapy rates are significantly higher by bronchoalveolar lavage than by tracheal aspirate. Intensive Care Med 2007, 33:1533-1540

109. Kaki R, Elligsen M, Walker S, Simor A, Palmay L, Daneman N: Impact of antimicrobial stewardship in critical care: a systematic review. J Antimicrob Chemother 2011, 66:1223-1230.

110. Kim JW, Chung J, Choi SH, Jang HJ, Hong SB, Lim CM, Koh Y: Early use of imipenem/cilastatin and vancomycin followed by de-escalation versus conventional antimicrobials without de-escalation for patients with hospital-acquired pneumonia in a medical ICU: a randomized clinical trial. Crit Care 2012, 16:R28.

111. Silva BN, Andriolo RB, Atallah AN, Salomao R: De-escalation of antimicrobial treatment for adults with sepsis, severe sepsis or septic shock. Cochrane Database Syst Rev 2013, 3: CD007934.
112. Bliziotis IA, Samonis G, Vardakas KZ, Chrysanthopoulou S, Falagas ME: Effect of aminoglycoside and beta-lactam combination therapy versus beta-lactam monotherapy on the emergence of antimicrobial resistance: a meta-analysis of randomized, controlled trials. Clin Infect Dis 2005, 41:149-158

113. Brunkhorst FM, Oppert M, Marx G, Bloos F, Ludewig K, Putensen C, Nierhaus A, Jaschinski U, Meier-Hellmann A, Weyland A, Grundling M, Moerer O, Riessen R, Seibel A, Ragaller M, Buchler MW, John S, Bach F, Spies C, Reill L, Fritz H, Kiehntopf M, Kuhnt E, Bogatsch H, Engel C, Loeffler M, Kollef MH, Reinhart K, Welte T, German Study Group Competence Network Sepsis (Sepnet): Effect of empirical treatment with moxifloxacin and meropenem vs meropenem on sepsis-related organ dysfunction in patients with severe sepsis: a randomized trial. JAMA 2012, 307:2390-2399.

114. Chamot E, Boffi El Amari E, Rohner P, Van Delden C: Effectiveness of combination antimicrobial therapy for pseudomonas aeruginosa bacteremia. Antimicrob Agents Chemother 2003, 47:2756-2764.

115. Cometta A, Calandra T, Gaya H, Zinner SH, de Bock R, Del Favero A, Bucaneve G, Crokaert F, Kern WV, Klastersky J, Langenaeken I, Micozzi A, Padmos A, Paesmans M, Viscoli C, Glauser MP: Monotherapy with meropenem versus combination therapy with ceftazidime plus amikacin as empiric therapy for fever in granulocytopenic patients with cancer. The International Antimicrobial Therapy Cooperative Group of the European Organization for Research and Treatment of Cancer and the Gruppo Italiano Malattie Ematologiche Maligne dell'Adulto Infection Program. Antimicrob Agents Chemother 1996, 40:1108-1115.

116. Dupont H, Carbon C, Carlet J: Monotherapy with a broad-spectrum beta-lactam is as effective as its combination with an aminoglycoside in treatment of severe generalized peritonitis: a multicenter randomized controlled trial, The Severe Generalized Peritonitis Study Group. Antimicrob Agents Chemother 2000, 44:2028-2033.

117. Falagas ME, Matthaiou DK, Bliziotis IA: The role of aminoglycosides in combination with a beta-lactam for the treatment of bacterial endocarditis: a meta-analysis of comparative trials. $J$ Antimicrob Chemother 2006, 57:639-647.

118. Furno P, Bucaneve G, Del Favero A: Monotherapy or aminoglycosidecontaining combinations for empirical antibiotic treatment of febrile neutropenic patients: a meta-analysis. Lancet Infect Dis 2002, 2:231-242.

119. Heyland DK, Dodek P, Muscedere J, Day A, Cook D: Randomized trial of combination versus monotherapy for the empiric treatment of suspected ventilator-associated pneumonia. Crit Care Med 2008, 36:737-744.

120. Kumar A, Safdar N, Kethireddy S, Chateau D: A survival benefit of combination antibiotic therapy for serious infections associated with sepsis and septic shock is contingent only on the risk of death: a meta-analytic/meta-regression study. Crit Care Med 2010, 38:1651-1664

121. Paul M, Silbiger I, Grozinsky S, Soares-Weiser K, Leibovici L: Beta lactam antibiotic monotherapy versus beta lactam-aminoglycoside antibiotic combination therapy for sepsis. Cochrane Database Syst Rev 2006, 1: CD003344.

122. Tamma PD, Cosgrove SE, Maragakis LL: Combination therapy for treatment of infections with Gram-negative bacteria. Clin Microbiol Rev 2012, 25:450-470.

123. Marcus R, Paul M, Elphick H, Leibovici L: Clinical implications of betalactam-aminoglycoside synergism: systematic review of randomised trials. Int J Antimicrob Agents 2011, 37:491-503.

124. Pena C, Suarez C, Ocampo-Sosa A, Murillas J, Almirante B, Pomar V, Aguilar M, Granados A, Calbo E, Rodriguez-Bano J, Rodriguez F, Tubau F, Oliver A, Martinez-Martinez $\mathrm{L}$ : Effect of adequate single-drug vs combination antimicrobial therapy on mortality in pseudomonas aeruginosa bloodstream infections: a post hoc analysis of a prospective cohort. Clin Infect Dis 2013, 57:208-216.

125. Woodhead M, Blasi F, Ewig S, Huchon G, Leven M, Ortqvist A, Schaberg T, Torres A, van der Heijden G, Verheij TJ: Guidelines for the management of adult lower respiratory tract infections. Eur Respir J 2005, 26:1138-1180.

126. Solomkin JS, Mazuski JE, Bradley JS, Rodvold KA, Goldstein EJ, Baron EJ, O'Neill PJ, Chow AW, Dellinger EP, Eachempati SR, Gorbach S, Hilfiker M, May AK, Nathens AB, Sawyer RG, Bartlett JG: Diagnosis and management of complicated intra-abdominal infection in adults and children: guidelines by the surgical infection society and the Infectious Diseases Society of America. Clin Infect Dis 2010, 50:133-164. 
127. Combes A, Luyt CE, Fagon JY, Wolff M, Trouillet JL, Chastre J: Early predictors for infection recurrence and death in patients with ventilatorassociated pneumonia. Crit Care Med 2007, 35:146-154.

128. Dennesen PJ, van der Ven AJ, Kessels AG, Ramsay G, Bonten MJ: Resolution of infectious parameters after antimicrobial therapy in patients with ventilator-associated pneumonia. Am J Respir Crit Care Med 2001, 163:1371-1375.

129. Luna CM, Blanzaco D, Niederman MS, Matarucco W, Baredes NC, Desmery P, Palizas F, Menga G, Rios F, Apezteguia C: Resolution of ventilator-associated pneumonia: prospective evaluation of the clinical pulmonary infection score as an early clinical predictor of outcome. Crit Care Med 2003, 31:676-682.

130. Chastre J, Wolff M, Fagon JY, Chevret S, Thomas F, Wermert D, Clementi E, Gonzalez J, Jusserand D, Asfar P, Perrin D, Fieux F, Aubas S: Comparison of 8 vs 15 days of antibiotic therapy for ventilator-associated pneumonia in adults: a randomized trial. JAMA 2003, 290:2588-2598.

131. Micek ST, Ward S, Fraser VJ, Kollef MH: A randomized controlled trial of an antibiotic discontinuation policy for clinically suspected ventilatorassociated pneumonia. Chest 2004, 125:1791-1799.

132. Hedrick TL, McElearney ST, Smith RL, Evans HL, Pruett TL, Sawyer RG: Duration of antibiotic therapy for ventilator-associated pneumonia caused by non-fermentative gram-negative bacilli. Surg Infect (Larchmt) 2007, 8:589-598.

133. Capellier G, Mockly H, Charpentier C, Annane D, Blasco G, Desmettre T, Roch A, Faisy C, Cousson J, Limat S, Mercier M, Papazian L: Early-onset ventilator-associated pneumonia in adults randomized clinical trial: comparison of 8 versus 15 days of antibiotic treatment. PLoS One 2012, 7:e41290.

134. Dimopoulos G, Poulakou G, Pneumatikos IA, Armaganidis A, Kollef MH, Matthaiou DK: Short- vs long-duration antibiotic regimens for ventilatorassociated pneumonia: a systematic review and meta-analysis. Chest 2013, 144:1759-1767.

135. Pugh R, Grant C, Cooke RP, Dempsey G: Short-course versus prolongedcourse antibiotic therapy for hospital-acquired pneumonia in critically ill adults. Cochrane Database Syst Rev 2011, 10, CD007577.

136. Eliakim-Raz N, Yahav D, Paul M, Leibovici L: Duration of antibiotic treatment for acute pyelonephritis and septic urinary tract infection 7 days or less versus longer treatment: systematic review and metaanalysis of randomized controlled trials. J Antimicrob Chemother 2013, 68:2183-2191.

137. Havey TC, Fowler RA, Daneman N: Duration of antibiotic therapy for bacteremia: a systematic review and meta-analysis. Crit Care 2011, 15:R267.

138. Kyriakidou KG, Rafailidis P, Matthaiou DK, Athanasiou S, Falagas ME: Shortversus long-course antibiotic therapy for acute pyelonephritis in adolescents and adults: a meta-analysis of randomized controlled trials. Clin Ther 2008, 30:1859-1868.

139. Nobre V, Harbarth S, Graf JD, Rohner P, Pugin J: Use of procalcitonin to shorten antibiotic treatment duration in septic patients: a randomized trial. Am J Respir Crit Care Med 2008, 177:498-505.

140. Schuetz P, Briel M, Christ-Crain M, Stolz D, Bouadma L, Wolff M, Luyt CE, Chastre J, Tubach F, Kristoffersen KB, Wei L, Burkhardt O, Welte T, Schroeder S, Nobre V, Tamm M, Bhatnagar N, Bucher HC, Mueller B: Procalcitonin to guide initiation and duration of antibiotic treatment in acute respiratory infections: an individual patient data meta-analysis. Clin Infect Dis 2012, 55:651-662

141. Kopterides P, Siempos II, Tsangaris I, Tsantes A, Armaganidis A: Procalcitonin-guided algorithms of antibiotic therapy in the intensive care unit: a systematic review and meta-analysis of randomized controlled trials. Crit Care Med 2010, 38:2229-2241.

142. Matthaiou DK, Ntani G, Kontogiorgi M, Poulakou G, Armaganidis A, Dimopoulos G: An ESICM systematic review and meta-analysis of procalcitonin-guided antibiotic therapy algorithms in adult critically ill patients. Intensive Care Med 2012, 38:940-949.

143. Prkno A, Wacker C, Brunkhorst FM, Schlattmann P: Procalcitonin-guided therapy in intensive care unit patients with severe sepsis and septic shock - a systematic review and meta-analysis. Crit Care 2013, 17:R291.

144. Cotta MO, Roberts JA, Tabah A, Lipman J, Vogelaers D, Blot S: Antimicrobial stewardship of beta-lactams in intensive care units. Expert Rev Anti Infect Ther 2014, 12:581-595.
145. Dellit TH, Owens RC, MCGowan JE Jr, Gerding DN, Weinstein RA, Burke JP, Huskins WC, Paterson DL, Fishman NO, Carpenter CF, Brennan PJ, Billeter M, Hooton TM: Infectious Diseases Society of America and the Society for Healthcare Epidemiology of America guidelines for developing an institutional program to enhance antimicrobial stewardship. Clin Infect Dis 2007, 44:159-177.

146. Lawrence $\mathrm{KL}$, Kollef $\mathrm{MH}$ : Antimicrobial stewardship in the intensive care unit: advances and obstacles. Am J Respir Crit Care Med 2009, 179:434-438.

147. Davey P, Brown E, Fenelon L, Finch R, Gould I, Hartman G, Holmes A, Ramsay C, Taylor E, Wilcox M, Wiffen P: Interventions to improve antibiotic prescribing practices for hospital inpatients. Cochrane Database Syst Rev 2005, 4: CD003543.

148. Gomes Silva BN, Andriolo RB, Atallah AN, Salomao R: De-escalation of antimicrobial treatment for adults with sepsis, severe sepsis or septic shock. Cochrane Database Syst Rev 2010, 12: CD007934.

149. Weiss CH, Dibardino D, Rho J, Sung N, Collander B, Wunderink RG: A clinical trial comparing physician prompting with an unprompted automated electronic checklist to reduce empirical antibiotic utilization. Crit Care Med 2013, 41:2563-2569.

150. Weiss CH, Moazed F, McEvoy CA, Singer BD, Szleifer I, Amaral LA, Kwasny M, Watts CM, Persell SD, Baker DW, Sznajder JI, Wunderink RG: Prompting physicians to address a daily checklist and process of care and clinical outcomes: a single-site study. Am J Respir Crit Care Med 2011, 184:680-686.

151. Pestotnik SL, Classen DC, Evans RS, Burke JP: Implementing antibiotic practice guidelines through computer-assisted decision support: clinical and financial outcomes. Ann Intern Med 1996, 124:884-890.

152. Belletti D, Zacker C, Mullins CD: Perspectives on electronic medical records adoption: electronic medical records (EMR) in outcomes research. Patient Relat Outcome Meas 2010, 1:29-37.

153. Kullar R, Goff DA, Schulz LT, Fox BC, Rose WE: The 'Epic' challenge of optimizing antimicrobial stewardship: the role of electronic medical records and technology. Clin Infect Dis 2013, 57:1005-1013.

154. Leibovici L, Gitelman V, Yehezkelli Y, Poznanski O, Milo G, Paul M, Ein-Dor P: Improving empirical antibiotic treatment: prospective, nonintervention testing of a decision support system. J Intern Med 1997, 242:395-400.

155. Bailey TC, Ritchie DJ, McMullin ST, Kahn M, Reichley RM, Casabar E, Shannon W, Dunagan WC: A randomized, prospective evaluation of an interventional program to discontinue intravenous antibiotics at two tertiary care teaching institutions. Pharmacotherapy 1997, 17:277-281.

156. Ibrahim EH, Ward S, Sherman G, Schaiff R, Fraser VJ, Kollef MH: Experience with a clinical guideline for the treatment of ventilator-associated pneumonia. Crit Care Med 2001, 29:1109-1115.

157. Rimawi RH, Mazer MA, Siraj DS, Gooch M, Cook PP: Impact of regular collaboration between infectious diseases and critical care practitioners on antimicrobial utilization and patient outcome. Crit Care Med 2013, 41:2099-2107.

doi:10.1186/s13054-014-0480-6

Cite this article as: Luyt et al:: Antibiotic stewardship in the intensive care unit. Critical Care 2014 18:480. 